TECHNICAL SCIENCES AND TECHNOLOGIES

UDC 681.5

DOI: $10.25140 / 2411-5363-2019-4(18)-141-147$

Patrik Šarga, Tomáš Záboly

\title{
MODERNIZATION OF THE TRANSPORT SYSTEM CONTROL OF THE PRODUCTION SYSTEM
}

Urgency of the research. Nowadays, it is crucial to keep up with modern technologies. Therefore, this work aims to modernize the production system Festo MPS 500. Thanks to this, it will be possible to apply to the system technologies meeting the latest trends in Industry 4.0. The MPS 500 system prepared in this way can be used to research new trends in accordance with Industry 4.0. The modernized MPS 500 system will also find use in the education of students in the field of automation and mechatronics so that they are sufficiently prepared for practice.

Target setting. The goal of the research was to modernize the transport system of the modular production system Festo MPS 500 according to Industry 4.0 platform.

Actual scientific researches and issues analysis. When upgrading the system MPS 500 and preparing this paper, we took into account both current sources - publications and papers dealing with the current state of Industry 4.0 and modular production systems as well as existing modular production systems based on Industry 4.0 platform.

Uninvestigated parts of general matters defining. At this stage of the research, data acquisition from the system MPS 500 and interconnection with the cloud was not realized.

The research objective. The purpose of this article is to modernize the MPS 500, which will allow focusing on Industry 4.0 research specifically for the deployment of Cyber-physical systems, Internet of Things, Big Data, Cloud Computing.

The statement of basic materials. Effective research of the new technologies in the industry requires to use modern systems which meet the criteria of Industry 4.0 platform. So the original system Festo MTS 500 was upgraded by systems from Siemens.

Conclusions. The main aim of this work was to modernize the transport system of the production system MPS 500. Elements of the system management were changed, and a new control program was created in the TIA Portal environment. The functionality of the MPS 500 was subsequently verified, where the full functionality of the system was confirmed. It makes the MPS 500 ready for further expansion in accordance with Industry 4.0.

Keywords: automation; control; modular production system; transport system; PLC; Industry 4.0

Fig.: 9. References: 12 .

Introduction. Festo MPS 500 (Fig. 1) is an educational modular production system that helps to teach mechatronics and automation [1]. It consists of a central transport system (conveyor), process station, entry and exit station and assembly station with a robot. The transport system (Fig. 2) is the brain of the MPS 500. Transport trolleys are used to move the assembled components on the line. Up to 4 components can be placed on each trolley. All stations are interconnected with the transport system. Control of the stations and transport system is conducted by programmable logic controllers (PLCs). Communication between individual stations and the conveyor is ensured via I/O (input / output) ports and AS-i (Actuator / Sensor interface) [2], [3].

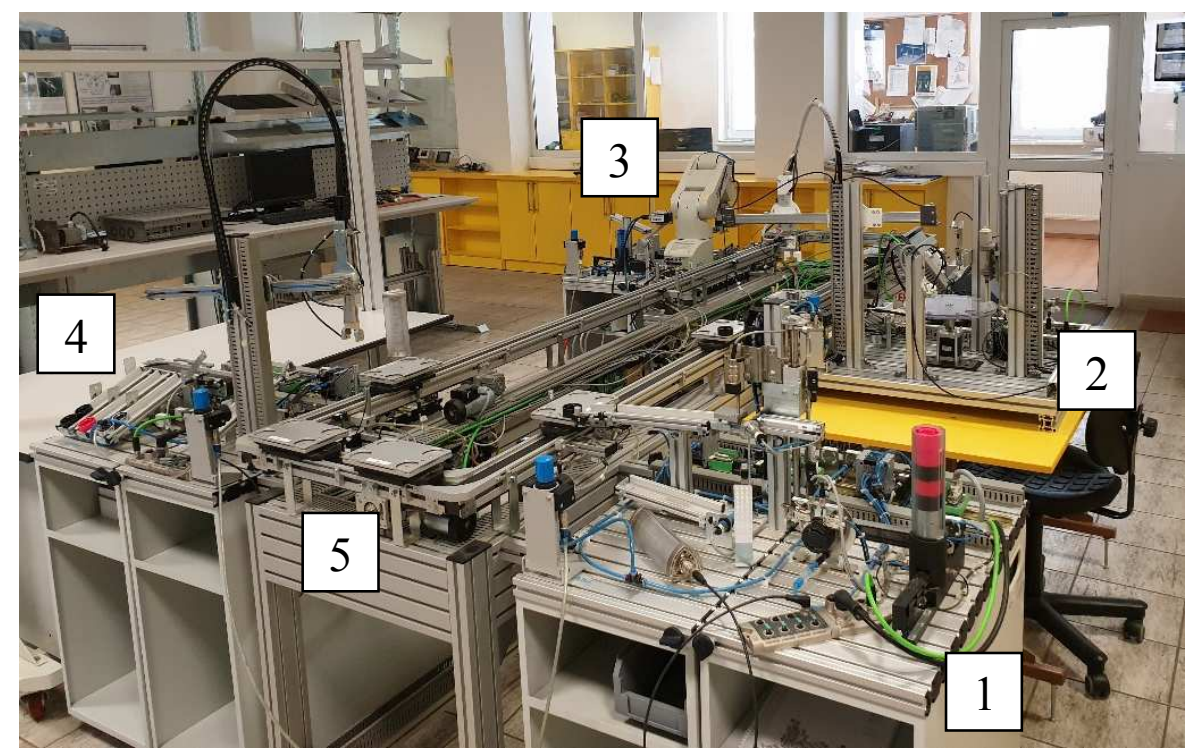

Fig. 1. Festo MPS 500:

1 -distribution and testing station, 2 - process station, 3 - assembly station with a robot, 4 - handling and sorting station, 5 - transport system 


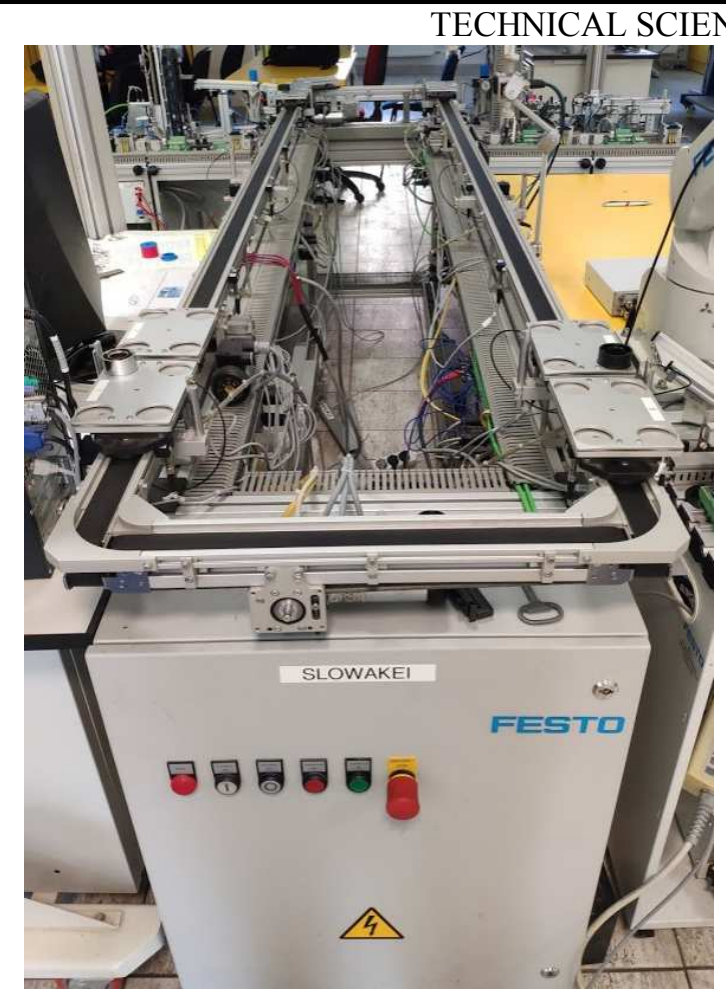

Fig. 2. Transport system of the MPS 500

All control elements of the transport system, including the PLC, frequency converter for motors and cabling, are located in the control cabinet. All these elements are supplied via the safety relay contacts. The original state of the control cabinet of the educational system MPS 500 before its modernization is shown in Fig. 3.

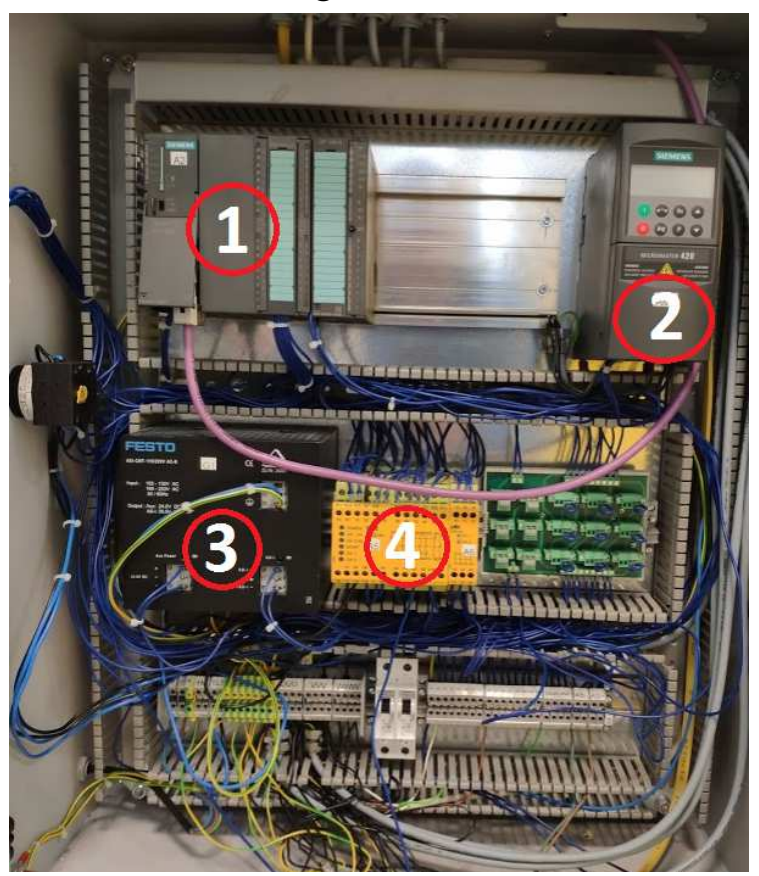

Fig. 3. The original state of the control cabinet:

1 - PLC Siemens SIMATIC S7-300 CPU 313c; 2 - Frequency converter Siemens MICROMASTER 420; 3 -Power supply unit; 4 - Safety relay pilz $x 9$

Modernization of the transport system. The main criterion in the modernization of the transport system of the MPS 500 was the use of modern components following Industry 4.0 [4]. MPS 500 is modular, so it can be extended to include stations that would perform other opera- 
TECHNICAL SCIENCES AND TECHNOLOGIES

tions, such as monitoring by a smart camera. With the camera, it is possible to monitor the correct machining of the component or to monitor the status of the component storage station. Later, it will be possible to extend the MPS 500 with sensors for detection of the trolley's presence, the presence of a component on the trolley, or the filling of the conveyor in front of the station.

Control system. Before the actual expansion of the MPS 500, it was necessary to upgrade the control by PLC. Since we decided to use the Profinet communication bus, it was necessary to use a switch with a suitable number of communication ports to connect the PLC with each station. The control PLC must communicate with the stations and synchronize them with the conveyor belt.

We chose the PLC S7-1500 CPU 1512C-1PN (Fig. 4) [5] as the control PLC. An important indicator for selecting a PLC was the fact that it has up to $32 \mathrm{I} / \mathrm{O}$ ports for further system expansion. Plus of the selected PLC is an integrated web server, which offers the possibility to display diagnostic and service information remotely. This PLC also has five analogue inputs that can be used to collect information from current, temperature, and other relevant sensors.

The SIMATIC S7-1500 PLC has two Profinet communication ports. This communication bus will also allow the system to access the Internet and connect it to the cloud. Another reason why we decided to use the SIMATIC S7-1500 PLC was that the lower-order PLC does not have enough computational power to process the amount of data retrieved from the sensors.

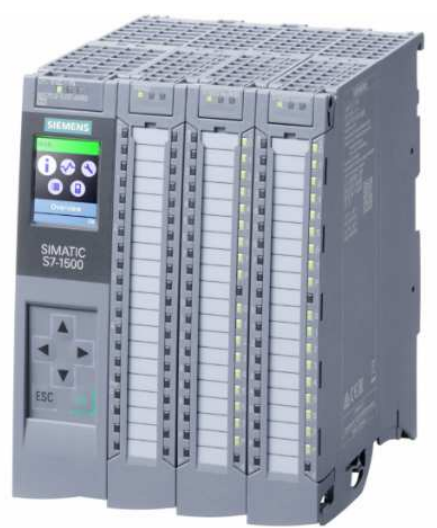

Fig. 4. PLC Siemens SIMATIC S7-1500 CPU 1512C-1PN [5]

The PLC does not provide a direct connection of the communication module, so it was necessary to use a decentralized peripheral. Siemens offers the SIMATIC ET 200 peripheral for this purpose.

SIMATIC ET 200 offers a wide range of distributed I/O systems. There is a version installed in the control cabinet or without the control cabinet, installed directly in harsh industrial environments. The device is also available with the protection up to IP67. [6]

A SIMATIC ET 200SP with IP20 protection was used for our needs (Fig. 5). It is easy to operate, ensuring maximum economy in a switchboard with a compact design and high performance [7].

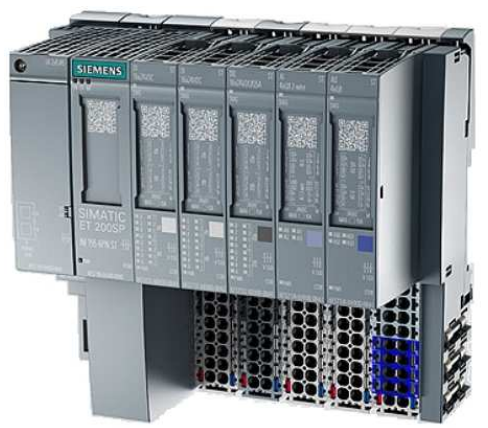

Fig. 5. SIMATIC ET 200SP [7] 
TECHNICAL SCIENCES AND TECHNOLOGIES

To the decentralized peripheral SIMATIC ET 200SP, it was also necessary to connect an additional module AS-i Master, which is a communication module for AS-Interface. The AS-i master allows simple "field" devices to be connected to the SIMATIC ET 200SP via the ASInterface. Several AS-i Master modules can be connected to one SIMATIC ET 200SP. [8]. Fig. 6 shows the ET 200SP peripheral with AS-i mastic attached.

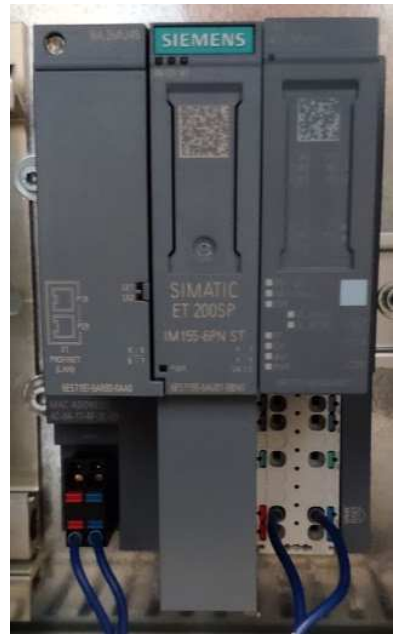

Fig. 6. SIMATIC ET 200SP with AS-i Master [8]

Frequency converter. SINAMICS G120 from Siemens has been selected from the offer of frequency converters (Fig. 7). It is a modular frequency converter for a variety of asynchronous motor control applications. Various converter variants allow a wide power range from 0.55 to $250 \mathrm{~kW}$. This series of converters are available in three voltage variants for connection to $200 \mathrm{~V}, 400 \mathrm{~V}$ and $690 \mathrm{~V}$. Each SINAMICS G120 series frequency converter consists of a control unit and a power unit. In the SINAMICS G120 series, each control unit can be combined with each power unit.

The control unit controls and monitors the power unit and the connected motor with the choice of the control method. It enables communication with central or local control as well as with monitoring devices.

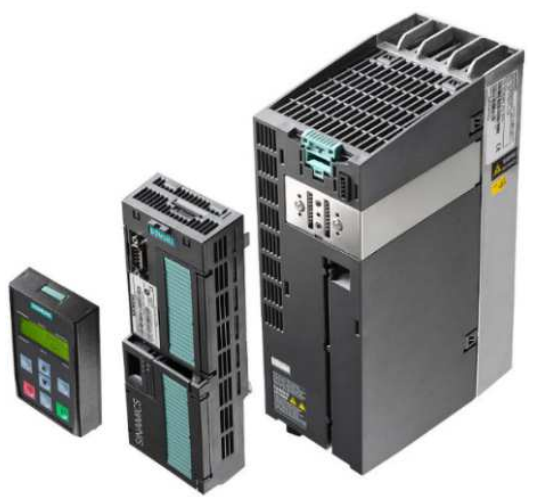

Fig. 7. Frequency converter Siemens SINAMICS G120 [9]

Basic functions of the SINAMICS G120 converter [10]:

- vector, torque control with or without speed feedback,

- precise stopping for a defined number of shaft (engine) revolutions,

- possibility to measure speed, frequency, current, temperature, torque, voltage, motor power,

- fixed power frequency or potentiometer for setting the engine speed,

- diagnostics and fault reporting,

- an automatic slow start after failure,

- adjustable switching frequency for silent motor operation. 
TECHNICAL SCIENCES AND TECHNOLOGIES

Installing new components. New components have been installed in the control cabinet PLC, decentralized peripheral SIMATIC ET 200SP, frequency converter SINAMICS G120 and SCALANCE X208 switch for interconnection of all PLCs used on the system MPS 500. These devices are mounted on a DIN rail. It was also necessary to connect the $24 \mathrm{~V}$ power supply to the SIMATIC ET 200SP. Subsequently, AS-i master and the PLC were connected with a network cable to SIMATIC ET 200SP. The final state of the control cabinet is shown in Fig. 8.

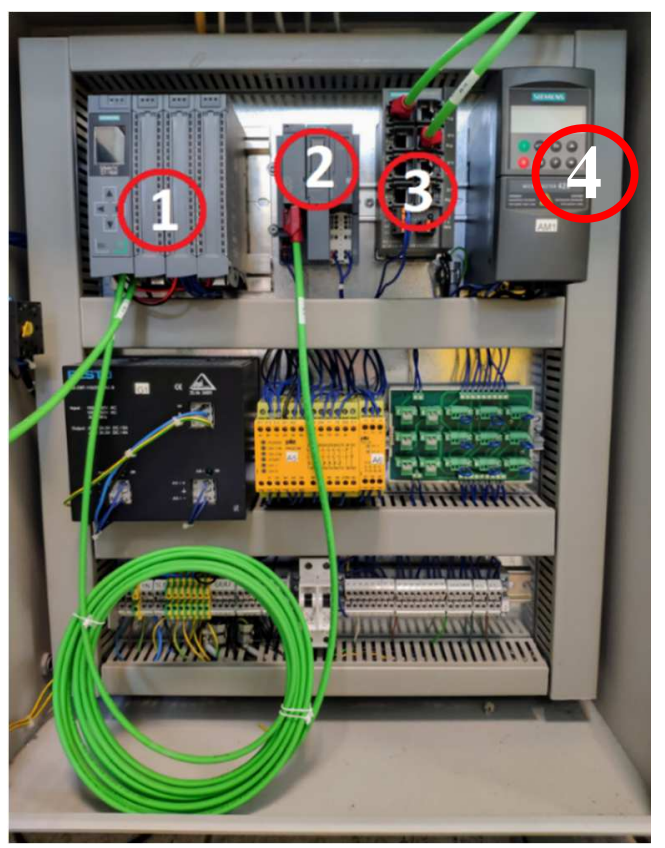

Fig. 8. The final state of the control cabinet:

1 - PLC Siemens SIMATIC S7-1500 CPU 1512C-1PN; 2 - SIMATIC ET 200SP;

3 - Switch SCALANCE X208; 4 - Frequency converter Siemens SINAMICS G120

The control program. After the hardware changes were made, it was necessary to create a new transport system control program to work with all stations in the MPS 500. The transport system must be able to respond to any conditions that may occur during MPS 500 operation (such as empty trolley in front of the station). The control program was created in TIA Portal in the LAD programming language.

TIA Portal (Totally Integrated Automation Portal) is Siemens software designed to create custom applications for PLCs, distributed peripherals, network components and communication components, HMI (human machine interface) panel design and extensive SCADA (Supervisory control and data acquisition) visualizations. All of this is integrated into a single software environment with an easy single-screen operation.

TIA Portal not only accelerates the creation of user applications but also has a transparent and straightforward structure. The resulting control program can be easily modified or supplemented. The program allows more accessible diagnostics in regular operation, including maintenance and service of automation technology. With its characteristic system features, TIA Portal supports the complete life cycle of the machine or devices [11].

Fig. 9 shows a demonstration of a control program that ensures the transport system cooperates with an assembly station with a robot.

Experimental verification of system functionality. The testing was carried out to verify the functionality of the whole system MPS 500. It was necessary to test all possible scenarios that might occur while the program was running in order to correct errors in the control program. The production cycle time required to test, process, assemble and sort one component was also measured. The identified shortcomings were subsequently remedied, and the resulting solution is fully operational [12]. 


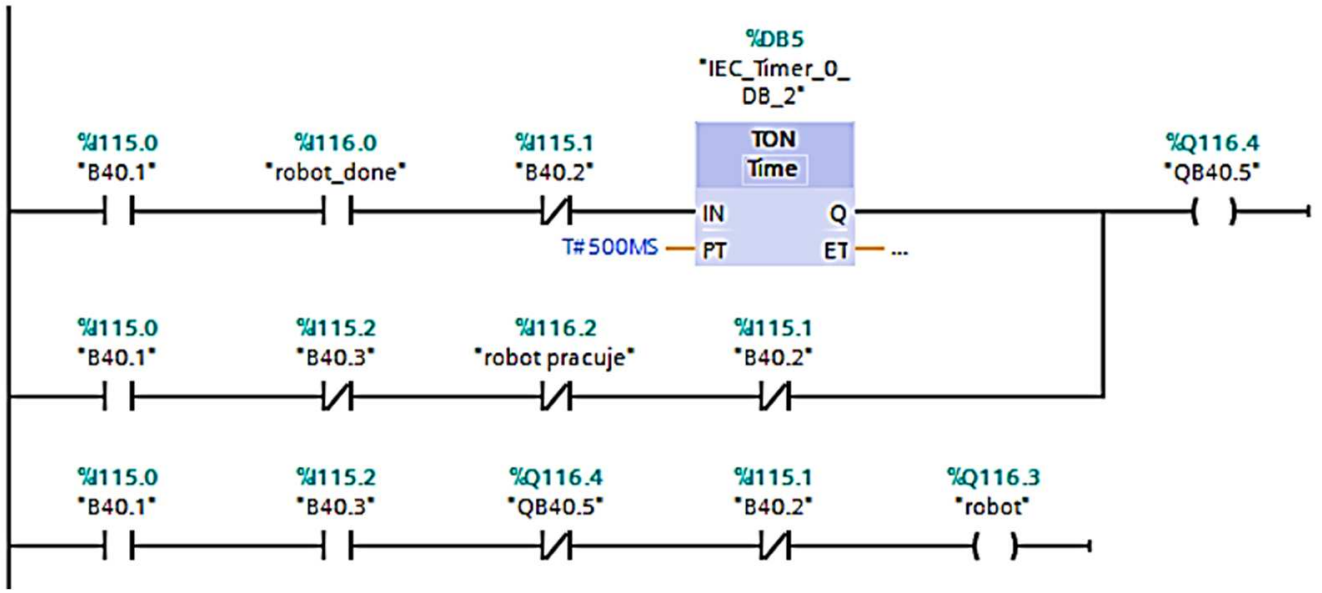

Fig. 9. Part of the control program

Conclusions. The main aim of this work was to modernize the transport system of the educational line MPS 500. Elements of the system management were changed, and a new control program was created in the TIA Portal environment. Used PLC and decentralized peripherals SIMATIC ET 200SP fulfil their task without problems, and the control of the movement of transport trolleys is performed as expected. All stations were connected via Profinet via SCALANCE X208 switch. The Siemens SINAMICS G120 frequency converter can measure current, temperature or torque values directly. The inverter has a port for connection to the PLC via Profinet, that is, it sends the measured values directly via the data cable to the PLC, which processes them. It is also possible to parameterize the converter centrally via the PC, thus avoiding time-consuming parameter entry via the display or by using the buttons on the converter.

The next step in extending MPS 500 functions will be to implement an HMI panel on which will be the process visualized. The HMI panel also has a Profinet connection so it can be connected to the PLC via free ports on the switch. In the next phase, the MPS 500 will be supplemented with additional sensors to monitor multiple parameters. The MPS 500 also connects to the cloud, allowing remote control of the production process

Acknowledgement. This work was supported by grant project VEGA 1/0330/19.

\section{References}

1. Schober, (2012), FESTO MPS500 manual, Denkendorf, 52 p [in English].

2. AS-INTERFACE (2019), Retrieved from https://www.mmspektrum.com/clanek/co-je-systemas-interface.html [in Slovak].

3. Priemyselné komunikačné zbernice (2019), Retrieved from http://senzor.robotika.sk/pkom/ html/kapitola4.htm [in Slovak].

4. Šimšík, Dušan (2019): Základy automatizácie, Košice [in Slovak].

5. Vlastnosti PLC SIMATIC S7-1500-Digital factory (2019), Retrieved from http://stest1.etnetera. $\mathrm{cz} / \mathrm{ad} /$ current/index.php?ctxnh=7eaed34950\&ctxp=home_[in Czech].

6. SIMATIC ET 200 - For distributed automation solutions. (2019), Retrieved from https://www.automation.siemens.com/salesmaterial-as/brochure/en/brochure_SIMATIC-et200_en.pdf [in English].

7. Decentrální periferie SIMATIC ET 200SP Installation (2019), Retrieved from https://www.blaja.cz/archiv-clanku/decentralni-periferie-SIMATIC-et-200sp.html [in Czech].

8. CM AS-i Master ST ET200SP Manual (2019), Retrieved from https://support.industry. siemens. $\mathrm{com} / \mathrm{cs} / \mathrm{document} / 71756485 /$ manual-cm-as-i-master-st-for-SIMATIC-et-200sp?dti=0\&lc=en-AO [in English].

9. SINAMICS G120 - Modular (2019), Retrieved fromhttps://www.parmley-graham.co.uk/options/ three-phase/SINAMICS-g120-modular_[in English].

10. Manual G120 CU240B/E-2 (2019), Retrieved from https://www.downloads.siemens.com/ download-center/Download.aspx?pos=download\&fct=getasset\&id1=A6V10423925 [in English]. 
TECHNICAL SCIENCES AND TECHNOLOGIES

11. Totally Integrated Automation Portal - Digital Factory and Process Industries and Drives Siemens (2019), Retrieved from http://stest1.etnetera.cz/ad/current/index.php?ctxnh=2416f2e791\& ctxp=home_[in Czech].

12. Záboly, Tomáš (2019): Návrh a realizácia riadenia asynchrónneho motora pre dopravný systém experimentálnej linky, Košice, [in Slovak].

\section{УДК 681.5}

\section{Патрик Сарга, Томаш Заболи \\ МОДЕРНІЗАЦІЯ УПРАВЛІННЯ ТРАНСПОРТНОЮ СИСТЕМОЮ У ВИРОБНИЧІЙ СИСТЕМІ}

Актуальність теми дослідження. В даний час, вкрай важливо, щзоб йти в ногу з сучасними технологіями. Отже, ия робота спрямована на модернізацію виробничої системи Fеsto MPS 500. Завдяки иьому можна буде застосувати до системних технологій, що відповідають останнім тенденціям у Індустрії 4.0. Підготовлена таким чином система MPS 500 може бути використана для дослідження нових тендениій відповідно до Індустрї 4.0. Модернізована система MPS 500 також знайде застосування у навчанні студентів у галузі автоматики та мехатроніки, щчоб вони були достатньо підготовлені до практики.

Постановка проблеми. Метою дослідження була модернізація транспортної системи модульної виробничої системи Festo MPS 500 відповідно до платформи Індустрія 4.0.

Аналіз останніх досліджень і публікацій. Під час оновлення системи MPS 500 та підготовки даного документу ми врахували як сучасні джерела - публікації та статті, щзо стосуються сучасного стану Індустрії 4.0, так $i$ модульні виробничі системи, а також існуючі модульні виробничі системи на базі платформи Індустрія 4.0.

Виділення недосліджених частин загальної проблеми. На даному етапі досліджень збір даних із системи MPS 500 та взаємозв'язок з хмарою здійснено не було.

Постановка завдання. Метою иієї статті є модернізачія MPS 500, що дозволить зосередитися на дослідженнях Індустрії 4.0 спеціально для розгортання кіберфізичних систем, інтернету речей, великих даних, хмарних обчислень.

Виклад основного матеріалу. Ефективне дослідження нових технологій у галузі потребує використання сучасних систем, щзо відповідають критеріям платформи Індустрія 4.0. Отюсе, оригінальна система Fеsto MTS 500 була модернізована системами виробництва Siemens.

Висновки відповідно до статті. Основна мета иієї роботи полягала в модернізачії транспортної системи виробничої системи MPS 500. Елементи управління системою були змінені та створено нову програму управління в середовищі порталу ТIА. Потім функиіональність MPS 500 була перевірена, де була підтверджена повна функціональність системи. Це робить MPS 500 готовим до подальшого розширення відповідно до Індустрії 4.0.

Ключові слова: автоматизація; управління; модульна виробнича система; транспортна система; PLC; Iндустрія 4.0. Рис.: 9. Бібл.: 12.

Patrik Šarga - Doctor of Technical Sciences, Associate Professor, Department of Automation and Human Machine Interactions, Faculty of Mechanical Engineering, Technical University of Košice (Letna 9, 04200 Košice, Slovak Republic).

Патрик Сарга - доцент, кандидат технічних наук, Технічний університет Кошице (Letna 9, 04200 Košice, Slovak Republic).

E-mail: patrik.sarga@tuke.sk

Scopus Author ID: 15128102900

Tomáš Záboly - student of mechanical engineering, Faculty of Mechanical Engineering, Technical University of Košice (Letná 9, 04200 Košice, Slovak Republic).

Томаш Заболи - студент факультету механічної інженерії, Технічний університет Кошице (Letna 9, 04200 Košice, Slovak Republic).

E-mail: tomas.zaboly@student.tuke.sk 